Archives of Agriculture and Environmental Science

\title{
Long-term fertilization effect on yield and land productivity of rice-wheat cropping system of Bangladesh
}

\author{
Fahamida Akter ${ }^{1,2}$, Md. Mizanur Rahman ${ }^{1}$ and Md. Ashraful Alam ${ }^{1^{*}}$ (D) \\ ${ }^{1}$ Faculty of Graduate Studies, Department of Soil Science, Bangabandhu Sheikh Mujibur Rahman Agricultural University, Gazipur- \\ 1706, BANGLADESH \\ ${ }^{2}$ Plant Breeding Division, Bangladesh Rice Research Institute, Gazipur-1701, BANGLADESH \\ "Corresponding author's E-mail: sium2740@gmail.com
}

\section{ARTICLE HISTORY}

Received: 30 May 2019

Revised received: 03 June 2019

Accepted: 04 June 2019

\section{Keywords}

Fertilization

Land productivity index

Sustainable yield index

Yield

\begin{abstract}
A factorial study was carried out at Bangabandhu Sheikh Mujibur Rahman Agricultural University to determine the effect of long term fertilization on yield performance of T. aman rice and wheat. The experimental plot received different organic manures for the last 26 years (1988-2014). The organic manure cowdung, compost, green manure and rice straw were applied at the rate of $25,25,7.5$ and $1.5 \mathrm{t} \mathrm{ha}^{-1}$, respectively in a yearly sequence. Three levels of nitrogen viz., 0,75 and $100 \mathrm{~kg} \mathrm{ha}^{-1}$ for rice and 0,80 and $120 \mathrm{~kg} \mathrm{ha}^{-1}$ for wheat were applied. Application of nitrogen fertilizer along with organic manure significantly increased yield of rice and wheat. The highest rice grain yield was found in 2014 under the $\mathrm{N}_{75}$ and no manure treatment, which was $6.48 \mathrm{t} \mathrm{ha}^{-1}$ whereas grain yield of wheat was found maximum in 2008 from the interaction of $\mathrm{N}_{120}$ and rice straw application where yield was recorded $5.25 \mathrm{t} \mathrm{ha}^{-1}$. In ricewheat cropping sequence, the plots that received no nitrogen, LPI value was less than $2(0.80)$ in the observed years. When the plots were treated with nitrogen fertilizer showed LPI values $>2$ in 2008,2009, 2012 and 2013, which indicates the trend of higher productivity of land due to long term fertilization. The maximum sustainable yield index was found in rice (0.69)> wheat (0.40) with $100 \mathrm{~kg} \mathrm{ha}^{-1}$ and $120 \mathrm{~kg} \mathrm{ha}^{-1} \mathrm{~N}$ treatment respectively. So, Long term fertilization strategy can be effective way to improve the yield, land productivity and sustainable yield index of rice and wheat through rescheduling the rates of organic and inorganic fertilizers that ensure balanced supply of plant nutrients.
\end{abstract}

(C)2019 Agriculture and Environmental Science Academy

Citation of this article: Akter, F., Rahman, M.M. and Alam, M.A. (2019). Long-term fertilization effect on yield and land productivity of rice-wheat cropping system of Bangladesh. Archives of Agriculture and Environmental Science, 4(2): 249-255, https://dx.doi.org/10.26832/24566632.2019.0402019

\section{INTRODUCTION}

Rice is the staple food grain in Bangladesh and covers about $80 \%$ of the total cropped area accounting for over $90 \%$ of total grain production of Bangladesh. Wheat is the second most important food grain and is commonly grown after rice. Over $85 \%$ of the total wheat area of the country is preceded by transplanted monsoon rice grown from July to December (Saunders, 1991). It is the most important predominant cropping system in Bangladesh which played a significant role in the sustainable food security. But, in recent findings, there has been clear evidence of declining trends of rice and wheat yield (Chauhan et al.,
2012). The demand for production of rice will endure rising in the near future due to shrinkage of cultivable land and over population growth (Alam et al., 2019b). The productivity of ricewheat system in Bangladesh is declining year after year. One of the main constraints to rice and wheat production is low organic matter content and low indigenous nutrient supply (Biswas and Sharma, 2008). Modern varieties give higher crop yields but respond to more nutrients than local varieties because of higher amount of potential biomass production. On an average, the farmers of Bangladesh use $190 \mathrm{~kg}$ nutrients ( $149 \mathrm{~kg} \mathrm{~N}, 16 \mathrm{~kg}$ P, $18 \mathrm{~kg} \mathrm{~K}$ and others $7 \mathrm{~kg}$ ) ha ${ }^{-1} \mathrm{yr}^{-1}$, while the estimated removal is around 280-350 kg/ha/yr. (Islam, 2008). The cumulative 
negative nutrient balance over the years resulted in the fertility degradation of land. Consequently, soils are degrading day by day, losing their health and potentiality for crop production (Khan et al., 2008).

Soil is an essential non-renewable resource with potentially rapid degradation rates and extremely slow formation and regeneration processes (Van-Camp et al., 2004). Most of the cultivable lands are degraded day by day due to indiscriminate use of agro-chemicals, excessive and deep tillage, luxury irrigation, intensive cropping with high yielding varieties, little or no use of organic materials and improper soil management practices (Lal, 2008). Soil organic matter (SOM) content in Bangladesh is not only poor but it is declining gradually which is the number one key to soil fertility and productivity.

Rice-wheat cropping system is the most adopted and vital cropping system for achieving food security of Asia (Ray and Gupta, 2001; Singh et al., 2007) and sustainability of this system is very important. Intensive cropping of rice-wheat system with no return of crop residues and other organic materials results in loss of soil organic matter and may have some adverse deleterious effect on soil fertility as well as production provided utmost care is not taken and thus the system is not sustainable (Samui et al., 1998; Singh et al., 2007). As the optimum soil physical environment for the puddled rice and upland wheat differs substantially, cropping sequence that includes both the crops requires special management practices like manuring to become sustainable (Islam, 1994; Singh et al., 2007). The necessary removal of organic material in the form of harvested crop is compensated for by growing green manure crops or by amending with compost. Long-term experiments play an important role in understanding the complex interaction involving plants, soils, climate and management practices and their effects on crop productivity. In fact, agricultural scientists have recognized the long-term sites as invaluable tools in the study of agroecosystem dynamics. To improve or to sustain the productivity of rice-wheat system in Bangladesh, Bhuiyan et al. (1993) recommended the long-term evaluation of the use of organic manure or green manure for maintaining soil fertility. It is now essential to increase organic matter content through periodic addition of organic matter along with the application of inorganic fertilizer for maintaining productivity to achieve maximum and stabilized crop yield in the country. A comprehensive breakthrough and capturing knowledge on the transformation of soil organic matter and $\mathrm{N}$ in soils is necessary to escalate soil fertility management practices and increase crop productivity, which may ensure food security and play a vital role in climate change mitigation (Alam et al., 2019a).

Studies by Bhandari et al. (2002) attributed the productivity of the rice-wheat system is reduced due to declining SOM, decreased soil fertility, occurrence of nutrient imbalances, and inappropriate fertilizer practices. Previous research considered that the continued use of mineral fertilizers may result in decline of soil productivity. In most long-term experiments, a combination of mineral fertilizers and organic manure has generally given the best crop yield and soil quality (Wang et al., 2004; Chalk et al., 2003). Therefore, present investigation was undertaken to observe the performance of the integrated use of organic manure and chemical fertilizer to assess the yield and land productivity in a rice-wheat cropping system. To achieve this goal an experiment was initiated in 1988 to study the effect of long term manuring along with three doses of nitrogen on soil properties and yield of T. aman rice and wheat. The present study utilized the yield data generated during 2007 to 2014 from the Long-Term Experiment (LTE).

\section{MATERIALS AND METHODS}

\section{Description of study site}

The current study is a part of long-term manuring experiment that started in July, 1988 with T. aman rice-wheat cropping sequence at Bangabandhu Sheikh Mujibur Rahman Agricultural University. Data used in the study for the period of 2007-2014, while as per design and treatments, the experiment was conducted for one year only (2013-2014). The experimental farm is located in the center of the Agro-ecological Zone (AEZ) of Madhupur Tract (AEZ-28) at about $24.23^{\circ}$ North Latitude and $90.08^{\circ}$ East Longitude having a mean elevation of $8.4 \mathrm{~m}$ above mean sea level and about $40 \mathrm{~km}$ north of Dhaka. The climate of the location is tropical monsoon. The land selected for the long-term experiment had been a virgin land where no crop was grown before. The soil belongs to Salna series representing the Shallow Red Brown Terrace and is classifed as Inceptisols according to USDA Taxonomy (Brammer, 1978). The soil is characterized by heavy clays within $50 \mathrm{~cm}$ from the surface and is acidic in nature. Some basic chemical properties of the soil, prior to setting the Long term experiment, are presented in the Table 1.

Table 1. Chemical properties of initial soil (0-15 cm) of the long-term experimental plot (Islam, 2003).

\begin{tabular}{lll}
\hline Parameters & 1988 & 2003 \\
\hline $\mathrm{pH}$ & 5.60 & 5.88 \\
Organic carbon (\%) & 0.42 & 0.30 \\
Total nitrogen (\%) & 0.03 & 0.05 \\
\hline
\end{tabular}




\section{Experimental design}

The experimental design of the study was in a factorial randomized complete block design with two replications and plot size was $12 \mathrm{~m} \times 7 \mathrm{~m}$. The factorial experiment included five different organic materials treatments (application of cow-dung (CD) @ 25 t/ha, compost @ 25 t/ha, green ipil-ipil leaves @ 7.5 t/ha, rice straw (RS) @ $1.5 \mathrm{t} / \mathrm{ha}$, no manure application) and three nitrogen treatments (For rice 0, 75 and $100 \mathrm{~kg} \mathrm{~N} / \mathrm{ha}$ and for wheat 0, 80 and $120 \mathrm{~kg} \mathrm{~N} / \mathrm{ha}$ ). The high yielding rice variety BRRI dhan39 and wheat variety BARI Gom 24 (prodip) were used as the test crops. Seeds were collected from Bangladesh Agricultural Development Corporation (BADC). One week after proper paddling the field, twenty-five-days old seedlings of BRRI dhan39 were transplanted maintaining a spacing of $25 \mathrm{~cm} \times 20$ $\mathrm{cm}$ and wheat seeds were directly sown in $18^{\text {th }}$ November 2013 in continuous lines having the line to line distance of $20 \mathrm{~cm}$. Fertilizer doses of $\mathrm{P}$ and $\mathrm{K}$ were applied as triple super phosphate (TSP)and muriate of potash (MoP) at the rate of 44.05 and $66.67 \mathrm{~kg}$ ha-1) The whole amount of TSP, MoP and gypsum was applied during final land preparation. Urea was applied in three equal splits at final land preparation, 15 days after transplanting (DAT) and 5-7 days before panicle initiation stage. During T. Aman 2013, irrigations were given to the rice plots to maintain standing water for almost all the time except maturity. Six irrigations were given on 5 Days after sowing (DAS), 11DAS, 21DAS, 29DAS, 40DAS and 50DAS during wheat season (Rabi 2014). After irrigation the soil was made loosen. Weeding and thinning were also done simultaneously at that time. At maturity BRRI dhan39 was harvested in $28^{\text {th }}$ September 2013 and BARI Gom 24 was harvested in 20 ${ }^{\text {th }}$ March 2014.

\section{Land Productivity Index (LPI)}

The yield data of rice and wheat for the year of 2007 to 2013 were collected from the records of previous study.

Land productivity index of rice and wheat were determined which were calculated using the following equation (Ranamukhaarachchi et al., 2005).

$$
\mathbf{L P I}=\sum_{i=1}^{n}\left(\frac{Y o b}{Y a v g}\right) \mathbf{i}
$$

Where, Yob = observed/actual yield of the ith crop (rice and wheat); Yavg = average yield of the ith crop (rice and wheat); $\mathrm{i}=$ the component crop grown in the cropping systems in a year; $\mathrm{n}=$ number of crops grown in the cropping systems in a year Although, the LPI offers the opportunity to use the potential crop yield to examine the contribution of cropping systems effect on yield gaps, as they reflect with the average productivity in the farming area. The LPI value of 2 was used as the standard value for determining the productivity of cropping systems containing two crops grown per year in sequence.

\section{Sustainable Yield Index (SYI)}

Sustainable yield index of rice and wheat were analyzed to determine the yield sustainability of rice and wheat. SYI of rice and wheat were calculated using the equation provided by Singh et al. (1990).

$S Y I=(y-s) / Y_{\max }$

Where, $y$ = estimated average yield; $s$ = standard deviation of yield across years; $Y_{\max }=$ maximum observed yield

SYI nearness to 1 implies the closeness to an ideal condition that can sustain maximum crop yields over year.

\section{Statistical analysis}

Data were statistically analyzed using STATISTICS-10.0 software. ANOVA and univariate analyses were performed to test all parameters. Treatment means were separated by least significant difference (LSD). Different graphs were prepared using Microsoft Excel (Office 2007).

\section{RESULTS AND DISCUSSION}

Yield of rice as influenced by long-term manuring and nitrogen fertilization in different years

The effect of manure and $\mathrm{N}$ fertilizer application on rice yield is presented in (Table 2). Manure and crop residues application did not show significant effect on rice yield except in 2012. Yields under different manure and residues treated plot ranged from 3.2 to $4.88 \mathrm{t} \mathrm{ha}^{-1}$. In 2007, the plots that received no nitrogen fertilizer yielded $2.10 \mathrm{t} \mathrm{ha}^{-1}$, which was increased to 4.82 and $4.87 \mathrm{t} \mathrm{ha}^{-1}$ grain in $\mathrm{N}_{75}$ and $\mathrm{N}_{100}$ treatments, respectively. It was found that rice yield significantly increased under $N_{75}$ and $N_{100}$ treatments over the control in all years since 2007 to 2014. However, there were insignificant differences found in rice yields between $N_{75}$ and $N_{100}$ treatments. Except the year 2007 and 2011, the yield of rice progressively increased from 2008 and onwards (Table 2). The highest grain yield (6.23 $\left.\mathrm{t} \mathrm{ha}^{-1}\right)$ was found in 2014 under the $\mathrm{N}_{75}$ treatment, which was insignificantly higher over the yield found in $\mathrm{N}_{100}$ treatment.

The interaction of nitrogen fertilizer and manure application was found significant (Table 2). The treatment that received no nitrogen and no manure or crop residues provided the lower yield of rice. The highest rice grain yield was found in 2014 under the $\mathrm{N}_{75}$ and no manure treatment, which was $6.48 \mathrm{t} \mathrm{ha}^{-1}$. However, this yield was insignificantly varied with the yields found under the interaction of $\mathrm{N}_{75}$ with different manures and $\mathrm{N}_{100}$ with different manure and residues. In IPNS, the integrated use of chemical fertilizer and organic manure enhanced growth and yield contributing characters of wheat and T. Aman rice in the wheat-rice cropping systems reported by Haque et al. (2018).

Yield of wheat as influenced by long-term manuring and nitrogen fertilization in different years

Long-term application of nitrogen fertilizer and manures exerted significant role on grain yield of wheat (Table 3). Nitrogen application provided significantly higher yields over the control treatment where no nitrogen was applied. Grain yield of wheat 
Table 2. Yield of rice as influenced by long-term manuring and nitrogen fertilization in different years.

\begin{tabular}{|c|c|c|c|c|c|c|c|c|c|}
\hline \multicolumn{3}{|l|}{ Treatments } & \multicolumn{7}{|c|}{ Rice yield $\mathrm{t} \mathrm{ha}^{-1}$ ) in different years } \\
\hline \multicolumn{2}{|l|}{ Nitrogen $\left(\mathrm{kg} \mathrm{ha}^{-1}\right)$} & 2007 & 2008 & 2009 & 2010 & 2011 & 2012 & 2013 & 2014 \\
\hline \multicolumn{2}{|l|}{0} & $2.10 \mathrm{~b}$ & $2.11 b$ & $2.13 \mathrm{~b}$ & $2.23 b$ & $2.17 \mathrm{~b}$ & $2.23 \mathrm{~b}$ & $2.17 \mathrm{~b}$ & $2.24 \mathrm{~b}$ \\
\hline \multicolumn{2}{|l|}{75} & $4.82 \mathrm{a}$ & $4.51 \mathrm{a}$ & $4.53 a$ & $4.95 a$ & $3.77 a$ & 4.89a & $4.46 a$ & $6.23 a$ \\
\hline \multicolumn{2}{|l|}{100} & $4.87 a$ & $4.76 a$ & $4.59 a$ & $4.85 a$ & $3.87 a$ & $4.86 a$ & $4.55 \mathrm{a}$ & $5.97 a$ \\
\hline \multirow{2}{*}{\multicolumn{2}{|c|}{$\begin{array}{l}\mathrm{SE}( \pm) \\
\text { Manure }\left(\mathrm{t} \mathrm{ha}^{-1}\right)\end{array}$}} & 0.12 & 0.15 & 0.21 & 0.19 & 0.09 & 0.09 & 0.26 & 0.20 \\
\hline & & & & & & & & & \\
\hline \multicolumn{2}{|l|}{0} & 3.85 & 3.73 & 3.78 & 4.05 & 3.18 & $3.81 \mathrm{~b}$ & 3.63 & 4.87 \\
\hline \multicolumn{2}{|l|}{$C D(25)$} & 4.05 & 3.88 & 3.80 & 3.93 & 3.29 & $4.08 a$ & 3.67 & 4.75 \\
\hline \multicolumn{2}{|l|}{ CP (25) } & 3.94 & 3.88 & 3.71 & 3.91 & 3.40 & $3.94 a b$ & 4.00 & 4.84 \\
\hline \multicolumn{2}{|l|}{ GM (7.5) } & 3.91 & 3.86 & 3.64 & 4.13 & 3.20 & $4.02 \mathrm{ab}$ & 3.57 & 4.80 \\
\hline \multicolumn{2}{|l|}{$\mathrm{RS}(1.5)$} & 3.90 & 3.63 & 3.81 & 4.02 & 3.28 & $4.11 a$ & 3.77 & 4.80 \\
\hline \multirow{2}{*}{\multicolumn{10}{|c|}{$\begin{array}{l}\mathrm{SE}( \pm) \\
\text { Nitrogen } \times \text { Manure }\end{array}$}} \\
\hline & & & & & & & & & \\
\hline \multicolumn{10}{|l|}{$\begin{array}{l}\text { Nitrogen } \\
\left(\mathrm{kg} \mathrm{ha}^{-1}\right)\end{array}$} \\
\hline 0 & 0 & $2.01 b$ & $2.03 d$ & $2.08 b$ & $2.03 b$ & $2.04 c$ & $2.04 d$ & $2.03 b$ & $2.01 \mathrm{~b}$ \\
\hline 0 & $\mathrm{CD}(25)$ & $2.23 \mathrm{~b}$ & $2.13 d$ & $2.18 \mathrm{~b}$ & $2.18 \mathrm{~b}$ & $2.09 c$ & $2.13 d$ & $2.13 \mathrm{~b}$ & $2.18 \mathrm{~b}$ \\
\hline 0 & $\mathrm{CP}(25)$ & $2.10 b$ & $2.20 d$ & $2.13 b$ & $2.23 b$ & $2.16 c$ & $2.23 d$ & $2.23 b$ & $2.25 \mathrm{~b}$ \\
\hline 0 & GM (7.5) & $2.04 \mathrm{~b}$ & $2.08 d$ & $2.15 b$ & $2.28 b$ & $2.23 c$ & $2.43 d$ & $2.33 b$ & $2.48 \mathrm{~b}$ \\
\hline 0 & RS (1.5) & $2.13 b$ & $2.13 d$ & $2.13 \mathrm{~b}$ & $2.43 b$ & $2.33 c$ & $2.43 d$ & $2.33 b$ & $2.48 b$ \\
\hline 75 & 0 & $4.53 a$ & $4.17 \mathrm{bc}$ & $4.19 a$ & $5.13 a$ & 3.69ab & $4.78 b c$ & $4.65 a$ & $6.48 \mathrm{a}$ \\
\hline 75 & $\mathrm{CD}(25)$ & $5.03 a$ & 4.75abc & $4.97 a$ & $4.75 a$ & 3.81ab & $5.23 a$ & $4.42 a$ & $6.30 a$ \\
\hline 75 & CP (25) & $4.78 a$ & 4.63abc & $4.75 a$ & 4.63a & $4.03 a$ & $4.73 b c$ & $4.71 a$ & $5.98 a$ \\
\hline 75 & GM (7.5) & $5.00 \mathrm{a}$ & $4.94 a$ & $4.09 a$ & $5.13 a$ & $3.56 \mathrm{~b}$ & $4.90 a b c$ & $4.09 a$ & $6.03 a$ \\
\hline 75 & $\mathrm{RS}(1.5)$ & $4.75 a$ & $4.06 c$ & $4.63 a$ & $5.13 a$ & $3.75 a b$ & $4.80 \mathrm{bc}$ & $4.43 a$ & $6.38 a$ \\
\hline 100 & 0 & $5.00 a$ & $5.00 a$ & $5.06 a$ & $5.00 a$ & $3.82 a b$ & $4.60 c$ & $4.21 a$ & $6.13 a$ \\
\hline 100 & $\mathrm{CD}(25)$ & $4.90 a$ & $4.75 a b c$ & $4.25 a$ & $4.88 a$ & 3.97ab & $4.90 a b c$ & $4.46 a$ & $5.78 a$ \\
\hline 100 & $\mathrm{CP}(25)$ & $4.94 a$ & $4.81 \mathrm{ab}$ & $4.25 a$ & $4.88 a$ & $4.00 a$ & 4.88abc & $5.06 a$ & $6.30 a$ \\
\hline 100 & GM (7.5) & $4.69 a$ & $4.56 \mathrm{abc}$ & $4.69 a$ & $5.00 a$ & $3.81 \mathrm{ab}$ & $4.83 a b c$ & $4.48 a$ & $6.08 \mathrm{a}$ \\
\hline 100 & RS (1.5) & $4.81 a$ & 4.69abc & $4.69 a$ & $4.50 a$ & $3.75 a b$ & 5.10ab & $4.56 a$ & $5.55 a$ \\
\hline $\mathrm{SE}( \pm)$ & & 0.26 & 0.33 & 0.47 & 0.43 & 0.20 & 0.19 & 0.58 & 0.44 \\
\hline CV (\%) & & 6.71 & 8.81 & 12.55 & 10.68 & 6.13 & 4.76 & 15.65 & 9.17 \\
\hline
\end{tabular}

$\mathrm{M}_{0}=$ No manure, $\mathrm{CD}=$ cowdung @ $25 \mathrm{t} \mathrm{ha}^{-1}, \mathrm{CP}=$ Compost @ $25 \mathrm{t} \mathrm{ha}^{-1}, \mathrm{GM}=$ Green manure @ $7.5 \mathrm{t} \mathrm{ha}^{-1}, \mathrm{RS}=$ Rice straw @ $1.5 \mathrm{t}$ ha ${ }^{-1}, \mathrm{~N}_{0}=\mathrm{No}_{\text {nitrogen, }}$ $\mathrm{N}_{75}=75 \mathrm{~kg} \mathrm{Nha}^{-1}, \mathrm{~N}_{100}=100 \mathrm{~kg} \mathrm{~N} \mathrm{ha}^{-1}$. Means followed by same letter (s) in a column do not differ significantly at $5 \%$ by LSD.

Table 3. Yield of wheat as influenced by long-term manuring and nitrogen fertilization in different years.

\begin{tabular}{|c|c|c|c|c|c|c|c|}
\hline \multirow{2}{*}{$\begin{array}{l}\text { Treatments } \\
\text { Nitrogen }\left(\mathrm{kg} \mathrm{ha}^{-1}\right)\end{array}$} & \multicolumn{7}{|c|}{ Wheat yield $\left(\mathrm{t} \mathrm{ha}^{-1}\right)$ in different years } \\
\hline & & 2008 & 2009 & 2010 & 2011 & 2012 & 2013 \\
\hline 0 & & $1.24 \mathrm{c}$ & $1.29 \mathrm{~b}$ & $0.59 c$ & $0.83 \mathrm{~b}$ & $1.00 \mathrm{~b}$ & $1.38 \mathrm{c}$ \\
\hline 80 & & $4.33 b$ & $3.94 a$ & $2.49 b$ & $2.73 a$ & $2.88 a$ & $3.15 b$ \\
\hline 120 & & $4.99 a$ & $4.30 a$ & $3.20 \mathrm{a}$ & $2.75 a$ & $3.13 a$ & $3.89 a$ \\
\hline $\mathrm{SE}( \pm)$ & & 0.22 & 0.30 & 0.12 & 0.18 & 0.27 & 0.06 \\
\hline \multicolumn{8}{|l|}{ Manure $\left(\mathrm{t} \mathrm{ha}^{-1}\right)$} \\
\hline 0 & & 3.43 & 2.90 & 2.14 & 1.92 & 2.35 & $2.31 \mathrm{~d}$ \\
\hline $\mathrm{CD}(25)$ & & 3.28 & 3.31 & 2.02 & 2.03 & 2.24 & $2.52 \mathrm{c}$ \\
\hline CP (25) & & 3.52 & 3.49 & 2.24 & 2.14 & 2.68 & $2.67 c$ \\
\hline GM (7.5) & & 3.73 & 2.88 & 2.12 & 2.24 & 2.11 & $3.04 b$ \\
\hline $\mathrm{RS}(1.5)$ & & 3.63 & 3.30 & 1.94 & 2.19 & 2.31 & $3.50 a$ \\
\hline $\mathrm{SE}( \pm)$ & & 0.28 & 0.39 & 0.15 & 0.23 & 0.35 & 0.07 \\
\hline \multicolumn{8}{|l|}{ Nitrogen $\times$ Manure } \\
\hline $\begin{array}{l}\text { Nitrogen } \\
\left(\mathrm{kg} \mathrm{ha}^{-1}\right)\end{array}$ & $\begin{array}{l}\text { Manure } \\
\left(\mathrm{t} \mathrm{ha}^{-1}\right)\end{array}$ & & & & & & \\
\hline 0 & 0 & $1.30 c$ & $1.25 d$ & $0.78 d$ & $0.88 b$ & $0.88 \mathrm{~cd}$ & $0.90 \mathrm{i}$ \\
\hline 0 & $C D(25)$ & $1.50 c$ & $1.19 d$ & $0.63 d$ & $0.94 b$ & $0.81 \mathrm{~cd}$ & 1.03hi \\
\hline 0 & $\mathrm{CP}(25)$ & $1.05 c$ & $2.19 \mathrm{~cd}$ & $0.59 d$ & $0.72 b$ & $1.94 b c$ & $1.18 \mathrm{~h}$ \\
\hline 0 & GM (7.5) & $1.58 c$ & $0.90 \mathrm{~d}$ & $0.53 d$ & $0.94 b$ & $0.63 d$ & $1.58 \mathrm{~g}$ \\
\hline 0 & $\mathrm{RS}(1.5)$ & $0.75 c$ & $0.94 d$ & $0.41 d$ & $0.67 b$ & $0.75 c d$ & $2.20 f$ \\
\hline 80 & 0 & $4.25 a b$ & $3.81 \mathrm{ab}$ & $2.44 c$ & $2.50 a$ & $3.00 a b$ & $2.75 \mathrm{e}$ \\
\hline 80 & $\mathrm{CD}(25)$ & $3.50 \mathrm{~b}$ & $4.50 \mathrm{ab}$ & $2.38 c$ & $2.53 a$ & 2.89ab & $3.16 \mathrm{~d}$ \\
\hline 80 & $\mathrm{CP}(25)$ & $4.38 a b$ & $4.03 a b$ & $3.06 \mathrm{ab}$ & $2.97 a$ & $2.91 \mathrm{ab}$ & $3.23 d$ \\
\hline 80 & GM (7.5) & $4.63 a$ & $3.06 b c$ & $2.50 \mathrm{bc}$ & $2.91 a$ & $2.88 a b$ & $3.29 d$ \\
\hline 80 & RS (1.5) & $4.88 a$ & $4.28 \mathrm{ab}$ & $2.06 c$ & $2.75 a$ & $2.75 a b$ & $3.34 \mathrm{~cd}$ \\
\hline 120 & 0 & $4.75 a$ & 3.63abc & $3.19 a$ & $2.38 a$ & 3.19ab & $3.28 d$ \\
\hline 120 & $\mathrm{CD}(25)$ & $4.85 a$ & $4.25 a b$ & $3.06 a b$ & $2.63 a$ & 3.03ab & $3.36 \mathrm{~cd}$ \\
\hline 120 & $\mathrm{CP}(25)$ & $5.13 a$ & $4.25 a b$ & $3.06 a b$ & $2.72 a$ & 3.19ab & $3.60 c$ \\
\hline 120 & GM (7.5) & $4.98 a$ & $4.69 a$ & $3.33 a$ & $2.88 a$ & 2.83ab & $4.25 b$ \\
\hline 120 & $\mathrm{RS}(1.5)$ & $5.25 a$ & $4.69 a$ & $3.35 a$ & $3.13 a$ & $3.43 a$ & $4.95 a$ \\
\hline $\mathrm{SE}( \pm)$ & & 0.49 & 0.68 & 0.27 & 0.39 & 0.60 & 0.13 \\
\hline CV (\%) & & 13.87 & 21.31 & 12.75 & 18.77 & 25.70 & 4.48 \\
\hline
\end{tabular}

$\mathrm{M}_{0}=$ No manure, $\mathrm{CD}=$ cowdung @ $25 \mathrm{t} \mathrm{ha}^{-1}, \mathrm{CP}=$ Compost $@ 25 \mathrm{t} \mathrm{ha}^{-1}, \mathrm{GM}=$ Green manure @ $7.5 \mathrm{t} \mathrm{ha}^{-1}, \mathrm{RS}=$ Rice straw $@ 1.5 \mathrm{t}$ ha ${ }^{-1}, \mathrm{~N}_{0}=\mathrm{No} \mathrm{nitrogen}$ $\mathrm{N}_{80}=80 \mathrm{~kg} \mathrm{~N} \mathrm{ha}^{-1}, \mathrm{~N}_{120}=120 \mathrm{~kg} \mathrm{~N} \mathrm{ha}^{-1}$. Means followed by same letter (s) in a column do not differ significantly at $5 \%$ by LSD. 
was found significantly different between the $N_{80}$ and $N_{120}$ treatments in 2008, 2010 and 2013, while statistically similar yield was observed in 2009, 2011 and 2012. Manure application showed significant effect on wheat yield only in 2013 where rice straw application provided the highest yield which was $3.5 \mathrm{t} \mathrm{ha}^{-1}$ (Table 3). The interaction effect of nitrogen fertilizer and manure application was found significant in producing grain yield of wheat, where no nitrogen and no manure gave the lowest yield. In most of the cases nitrogen application at the rate of 80 and $120 \mathrm{~kg} \mathrm{ha}^{-1}$ with or without different manures did not show significant differences in wheat yield except in the year 2013. The highest grain yield of wheat was found in 2008 from the interaction of $\mathrm{N}_{120}$ and rice straw application where yield was recorded $5.25 \mathrm{t} \mathrm{ha}^{-1}$. Combined applications of organic and chemical fertilizers are more effective than sole application of organic or chemical fertilizers for sustainable Wheat and soil productivity enhancement (Chekolle, 2017).

Land productivity index (LPI) of rice and wheat

Since the types of crop yields were different, land productivity index (LPI) was developed to use a common basis for comparing cropping systems having different crops. When assuming the LPI of a single crop is one, two-crop cropping sequence will have theoretically a LPI of two. If the calculated LPI exceeds the theoretical LPI, the cropping system is considered to be biologically productive.

Effect of long-term application of nitrogen and manure on land Productivity index (LPI) of rice and wheat

Long-term application of nitrogen produced greater significant role on the productivity of rice and wheat (Figure 1 ). In ricewheat cropping sequence, the plots that received no nitrogen, LPI value was less than $2(0.80)$ in the observed years. When the plots were treated with nitrogen fertilizer showed LPI values $>2$ in 2008, 2009, 2012 and 2013, which indicated the higher productivity when compared to long-term mean productivity. Although LPI values were slightly low in 2010 and 2011, they were also very close to two and would be economically sound.

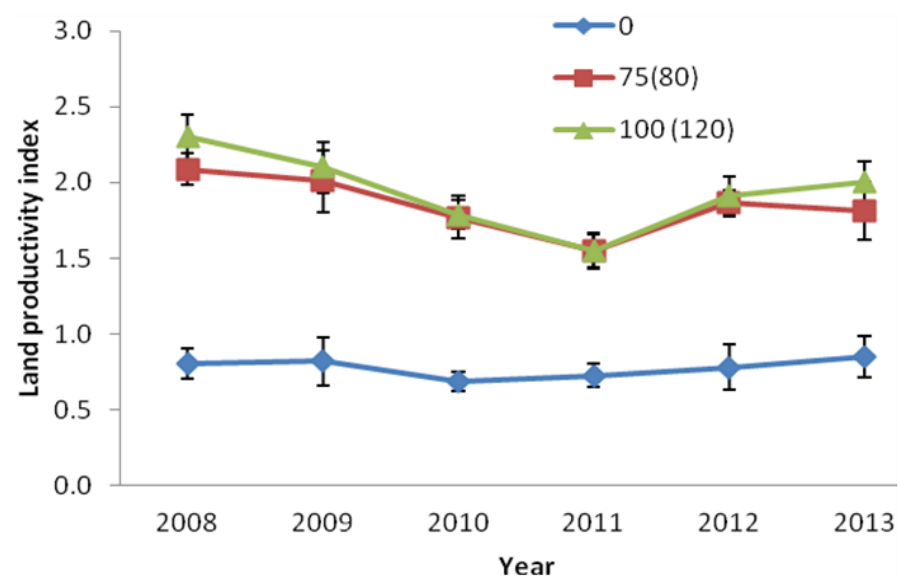

Figure 1. Effect of long-term application of different manure on LPI of rice and wheat (Vertical bars indicates standard errors).
The LPI value < 2 revealed that there is scope to increase yield of both rice and wheat through adoption of different modern soil and crop management practices.

Similar trend of results were observed in case of manure application (Figure 2). However in all cases of manure application the observed LPI values were much lower than theoritical LPI values of double crops cropping pattern. Therefore, there is also ample scope to increase the productivity of rice and wheat following different soil and crop management options. Rates of manure and residue application may need to refix to supply required amount of essential nutrients to crop plants. It also need to be confirmed that manures and residues are well composted before application to plots.

\section{Sustainable Yield Index (SYI) of rice and wheat}

Effect of long-term application of nitrogen and manure on sustainable yield Index (SYI) of rice and wheat

In case of rice, without application of nitrogen $\left(\mathrm{N}_{0}\right)$, the SYI of rice was 0.42 , which increased to 0.63 with $\mathrm{N}_{75}$ and 0.69 with $\mathrm{N}_{100}$ treatments, respectively (Figure 3 ). The maximum sustainable yield index (0.69) was found when $100 \mathrm{~kg} \mathrm{ha}^{-1}$ nitrogen was applied. SYI near to one implies that the closeness to an ideal condition that can sustain maximum crop yields over years, while deviation from one indicates the losses of sustainability (Singh et al., 1990). In case of wheat similar trend of result was observed (Figure 3). At zero nitrogen application SYI value for wheat was found 0.18 , while at 80 and $120 \mathrm{~kg} \mathrm{~N} /$ ha SYI values were 0.38 and 0.39 , respectively. It can be observed that SYI of rice was much higher than that of wheat. Nayak et al. (2012) also found that rice showed higher SYI value than wheat by conducting experiment in indo Gangetic plains of India.

Long-term application of manure has positive effects on the sustainability of rice and wheat (Figure 4). In case of rice, cow dung amended plots gave the maximum sustainable yield index (0.60) followed by RS and CP treated plots and the lowest SYI was found in the control treatment. In case of wheat, the highest SYI value (0.33) was obtained in the plots that received cow dung. Compost, green manure and rice straw applied plots showed slightly lower SYI value than that of cow dung applied plot. But all the SYI value of wheat was very low compared to standard SYI value. Effect of manure application on the yield of wheat was found unsustainable. Sustainability of grain yield of wheat must be achieved following improved management activities. SYI for wheat in both nitrogen and manure treatments were found very low compared to the standard SYI 1.0, and therefore there is ample scope to increase wheat yield. The rates of nitrogen fertilizer along with other micro and macro nutrients need to compute based on soil test nutrient values. Balanced fertilization should be ensured supplying either inorganic fertilizer or in combination of inorganic and organic fertilizers to get higher grain yield of wheat. Application of organic manures can be helpful in obtaining the sustainability of crop production was noted by Muhmood et al. (2015). 


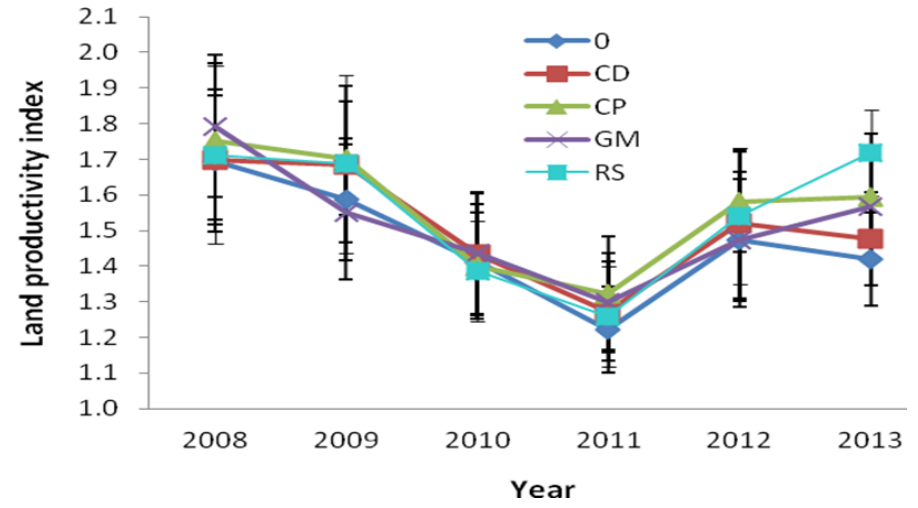

Figure 2. Effect of long-term application of nitrogen fertilizer on LPI of rice and wheat (Vertical bars indicates standard errors).

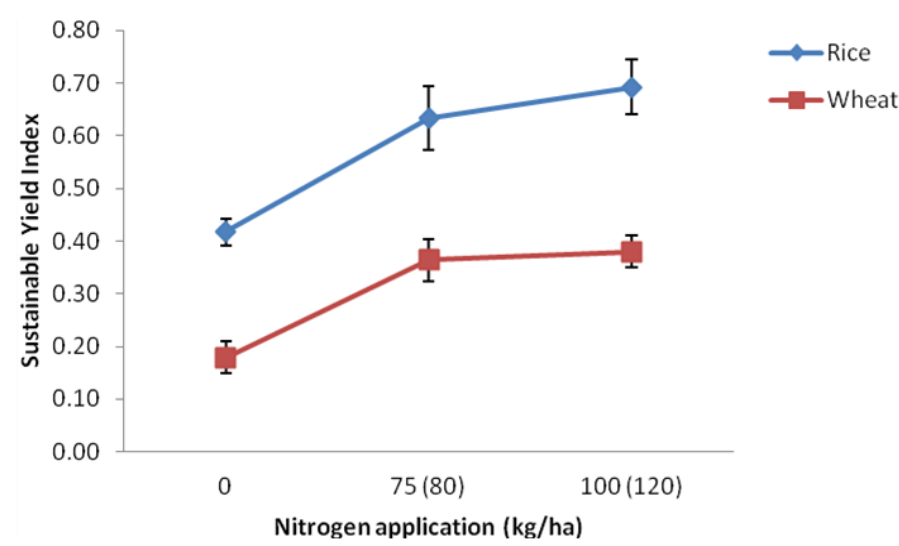

Figure 3. Effect of long-term application of different nitrogen on SYI of rice and wheat (Vertical bars indicates standard errors).

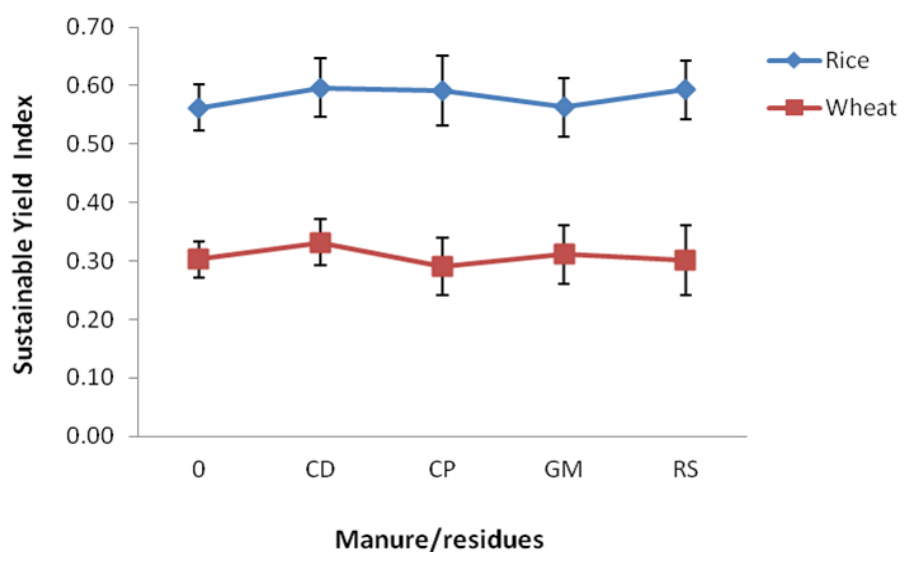

Figure 4. Effect of long-term application of different manure on SYI of rice and wheat (Vertical bars indicates standard errors).

\section{Conclusion}

From the experimental results it can be concluded that the combined use of organic manure with inorganic fertilizers performed better than inorganic fertilizers alone to sustain soil fertility and system productivity. Long-term addition of manures increased rice and wheat yield positively. In case of rice, the cow dung and rice straw performed better as compared to compost and green manure. In case of wheat, green manure and rice straw performed better. However, the yield increase due to organic amendment was not as much as obtained with $\mathrm{N}$ fertilizer application. Both LPI and SYI for rice and wheat were found low compared to the standard values which indicated that there are ample scopes to increase rice and wheat yields following better soil and crop management practices.

\section{ACKNOWLEDGEMENTS}

Authors impressively acknowledge Department of Soil Science, Bangabandhu Sheikh Mujibur Rahman Agricultural University, Gazipur-1706, Bangladesh for the financial (Grant No-BSMRAU/DSSC/2013) support to conduct this research.

\section{Conflict of interest \\ The authors declare there are no conflicts of interest.}

Open Access: This is an open access article distributed under the terms of the Creative Commons Attribution 4.0 License, which permits unrestricted use, distribution, and reproduction in any medium, provided the original author(s) if the sources are credited.

\section{REFERENCES}

Alam, M.A., Rahman, M.M., Kamal, M.Z., Kabir, H., Shiragi, M., Monira, S. and Hasnat, M. (2019a). A study on organic matter and nitrogen dynamics in wetland paddy soils of Bangladesh. Archives of Agriculture and Environmental Science, 4(1): 1-7, https://doi.org/10.26832/24566632.2019.040101

Alam, M.A., Rahman, M.M., Biswas, J.C., Akhter, S., Maniruzzaman, M., Choudhury, A.K. and Mannan, M.A. (2019b). Nitrogen transformation and carbon sequestration in wetland paddy field of Bangladesh. Paddy and Water Environment, 1-12, https://doi.org/10.1007/s10333-019-00693-7

Bhandari, A.L., Ladha, J.K., Pathak, H., Padre, A.T., Dawe, D. and Gupta, R.K. (2002). Yield and soil nutrient changes in a long-term rice-wheat rotation in India. Soil Science Society of America Journal, 66(1): 162-170, https://doi:10.2136/sssaj2002.1620

Bhuiyan, A.M., Badaruddin, M., Ahmed, N.U. and Razzaque, M.A. (1993). Rice-wheat system research in Bangladesh: A review. Wheat Research Centre, Bangladesh Agricultural Research Institute, Nashipur, Dinajpur, Bangladesh, https://scholar.google.com/scholar? clus-

ter $=13150903666971385686 \& \mathrm{hl}=$ en\&as_sdt $=2005 \&$ sciodt $=0,5 \&$ scioq $=\mathrm{Bh}$ uiyan,+A.M.,+Badaruddin,+M.,+Ahmed,+N.U.+and+Razzaque,+A.+(1993).+\% 09Conclu-

sion.+In:+RiceWheat+System+Research+in+Bangladesh:+A+Review.+\% 09Wheat+Research+Center,+Bangladesh+Agricultural+Research+Institute ,+Nashipur,+\%09Dinajpur,+Bangladesh.+pp.+83-84.+

Biswas, P.P. and Sharma, P.D. (2008). A new approach for estimating fertiliser response ratio-the Indian scenario. Indian Journal of Fertilisers, 4(7): 59.

Brammer, H. (1978). Rice Soils of Bangladesh. In: Soils and Rice. Manila, Philippines. The IRRI. pp. 35-55.

Chalk, P.M., Heng, L.K. and Moutonnet, P. (2003). Nitrogen fertilization and its environmental impact. In proceeding of 12th International World Fertilizer Congress', pp.1-15. Beijing, China.

Chauhan, B.S., Mahajan, G., Sardana, V., Timsina, J. and Jat, M.L. (2012). Productivity and sustainability of the rice-wheat cropping system in the Indo-Gangetic Plains of the Indian subcontinent: problems, opportunities, and strategies. In Advances in Agronomy, 117: 315-369, https://doi.org/10.1016/B978-0-12-394278-4.00006-4

Chekolle, A.W. (2017) Evaluation of synergistic effect organic and inorganic fertilizing system on grain yield of bread wheat (Triticum aestivum L.) at Southern Tigray, Northern Ethiopia. Advance in Crop Science Technology, 5:269, https://doi: 10.4172/2329-8863.1000269

Haque, M.A., Jahiruddin, M., Islam, M.S., Rahman, M.M. and Saleque, M.A. (2018). Effect of bioslurry on the yield of wheat and rice in the wheat-rice cropping system. Agricultural Research, 7(4): 432-442, https://doi.org/10.1007/s40003-018-0333-7

Islam, M. S. (2008). Soil fertility history, present status and future scenario in Bangladesh. Bangladesh Journal of Agriculture and Environment, 4: 129-151.

Islam, M.S. (2003). Impact of long-term application of organic matter on soil properties and crop production. Ph.D dissertation, Department of Soil Science. BSMRAU, Salna, Gazipur-1701, Bangladesh.

Islam, M.S., Amin, M.S. and Anwar, M.N. (1994). Integrated soil fertility 
management in Bangladesh. Paper presented at the workshop on Integrated Nutrient Management for Sustainable Agriculture held at SRDI. Dhaka. June 26-28, 1994.

Khan, A.U., Iqbal, M. and Islam, K.R. (2007). Dairy manure and tillage effects on soil fertility and corn yields. Bioresource Technology, 98(10): 1972-1979, https://doi.org/10.1016/j.biortech.2006.07.041

Lal, R. (2008). Soils and sustainable agriculture. A review. Agronomy for Sustainable Development, 28(1): 57-64, https://doi.org/10.1051/agro:2007025

Muhmood, A., Majeed, A., Niaz, A., Javid, S., Shah, S.S. and Shah, A.H. (2015). Nutrients uptake and the yield of okra and carrot in response to bioslurry and inorganic $\mathrm{N}$ fertilizers. International Journal of Plant \& Soil Science, 7(5): 297-305.

Nayak, A.K., Gangwar, B., Shukla, A.K., Mazumdar, S.P., Kumar, A., Raja, R. and Mohan, U. (2012). Long-term effect of different integrated nutrient management on soil organic carbon and its fractions and sustainability of rice-wheat system in Indo Gangetic Plains of India. Field Crops Research, 127: 129-139, https://doi.org/10.1016/j.fcr.2011.11.011

Ranamukhaarachchi, S.L. and Begum, M.M.R.S.N. (2005). Soil fertility and land productivity under different cropping systems in highlands and medium highlands of Chandina sub-district, Bangladesh. Asia-Pacific Journal of Rural Development, 15(1): 63-76, Available online at https://journals.sagepub.com/doi/pdf/10.1177/1018529120050105
Ray, S.S. and Gupta, R.P. (2001). Effect of green manuring and tillage practices on physical properties of puddled loam soil under rice-wheat cropping system. Journal of the Indian Society of Soil Science, 49(4): 670-678, Samui, R.C., Kundu, A. L., Mazumdar, D. and Mani, P.K. (1998). Integrated nutrient management in rice-wheat system in West Bengal. In Proc. Natl. Workshop on Long-term Soil Fertility Management and Integrated Plant Nutrient Supply. Indian Inst. Soil Sci., Bhopal, India, pp. 256-259,

Saunders, D.A. (1991). Report of an On-Farm Survey: Jessore and Kushtia: Farmers' Practices and Perceptions.

Singh, G., Jalota, S.K. and Singh, Y. (2007). Manuring and residue management effects on physical properties of a soil under the rice-wheat system in Punjab, India. Soil and Tillage Research, 94(1): 229-238, https://doi.org/10.1016/j.still.2006.07.020

Singh, R.P. (1990). Towards sustainable dryland agricultural practices. http://agris.fao.org/agris-search/search.do?recordID=US201300707470

Van-Camp, L., Bujarrabal, B., Gentile, A. R., Jones, R.J., Montanarella, L., Olazabal, C. and Selvaradjou, S.K. (2004). Technical working groups established under the thematic strategy for soil protection, http://citeseerx.ist.psu.edu/viewdoc/summary?doi=10.1.1.400.5923

Wang, K.R., Liu, X., Zhou, W. J., Xie, X.L. and Buresh, R.J. (2004). Effects of nutrient recycling on soil fertility and sustainable rice production. Journal of AgroEnvironment Science, 23(6): 1041-1045. 